\title{
Successful Ocreotide and Medium-Chain Triglyceride Therapy for Cylothorax in a Patient with Noonan Syndrome: Case Report
}

\author{
Noonan Sendromlu Bir Olguda Oktreotid ve \\ Orta Zincirli Yağ Asitleri Kullanılarak \\ Şilotoraksın Başarılı Tedavisi
}

Sumru BEDER, MD, ${ }^{a}$ Zinet Gül ERSOY, MD, ${ }^{\text {a }}$ Emine GÜLLÜ, MD, ${ }^{a}$ G. Eda UTINE, MD, Oya KAYACAN, MD, ${ }^{a}$ Demet KARNAK, MDa

${ }^{a}$ Department of Chest Diseases, Ankara University Faculty of Medicine, bDepartment of Pediatrics,

Division of Genetics,

Hacettepe University

Faculty of Medicine, Ankara

Geliş Tarihi/Received: 04.09 .2008

Kabul Tarihi/Accepted: 14.01.2009

Toraks Derneği 10. Yıllık Kongresi'nde kongre tebliği olarak sunulmuştur:

(Beder S, Ersoy ZG, Güllü E,

Utine GE, Kayacan O,

Karnak D. Noonan Sendromlu

Bir Şilotoraks Olgusunun Oktreotid ve Kısa Zincirli Yağ Asittleri IIle Başarılı

Tedavisi (PS-189). Toraks Derneği 10.

YIllık Kongresi, Bildiri Özet Kitabı Cilt 8 ,

Ek 2, 122s Beldibi-Kemer-Antalya,

25-29 Nisan, 2007.)

Yazışma Adresi/Correspondence: Demet KARNAK, MD

Ankara University Faculty of Medicine, Department of Chest Diseases, Ankara, TÜRKIYE/TURKEY

karnak@medicine.ankara.edu.tr

\begin{abstract}
Noonan syndrome (NS), is an autosomal dominant disorder commonly seen in childhood and is characterized by short stature, congenital heart defects and facial abnormalities (especially in adults) along with thoracic deformity. Lymphatic dysplasia can be seen with this syndrome causing chylothorax by development of fistulas between thoracic duct and pleural space or it can directly occur by malformation of thoracic lymphatic vessels. Hence, chylothorax can also be seen. Herein, we present a case with this syndrome and chylothorax secondary to possible lymphatic dysplasia. We achieved a great success with ocreotide and medium chain trigliserides in the management of chylothorax and hence suggest this therapy to other clinicians.
\end{abstract}

Key Words: Noonan syndrome; chylothorax

ÖZET Noonan sedromu (NS), otozomal dominant geçişli, çocukluk çağında görülen, kısa boy, konjenital kalp hastalığı, yüz anomalisi (özellikle erişkinde) ve toraks deformitesiyle seyreden bir hastalıktır. Lenfatik bozukluk Noonan olgularının \%20'den azında görülür. Böylelikle şilotoraks da gözlenebilir. Burada lenfatik displazi sonucu şilotoraks gelişen bir Noonan olgusunu sunuyoruz. Bu olguda octreotid ve orta zincirli yağ asitleriyle şilotoraks tedavisinde büyük başarı sağlanmıştır. Bu nedenle diğer klinisyenlere de bu tedavi yaklaşımını önermekteyiz.

Anahtar Kelimeler: Noonan sendromu; şilotoraks

Turkiye Klinikleri J Med Sci 2010;30(4):1402-5

\section{CASE REPORT}

57-year-old man* presented with large pleural effusion on the right side. He was suffering from chest pain and increasing dyspnea for Lthe previous month. He was $150 \mathrm{~cm}$ tall and had a mild mental re-
tardation. Facial features included hypertelorism, down-slanting palpebral fissures, bilateral ptosis and strabismus, and low-set and posteriorly rotated ears. A short neck, kyphoscoliosis and widely spaced nipples were evident as well as an anterior chest deformity with pectus carinatum superiorly and pectus excavatum inferiorly (Figure 1). Breath sounds were seriously diminished on the right hemi-thorax and grade $5 / 6$ pansystolic murmur was heard on the mitral focus.

\footnotetext{
${ }^{*}$ Informed consent was obtained from the patient for publishing his data in the scientific journal as a case report.
} 


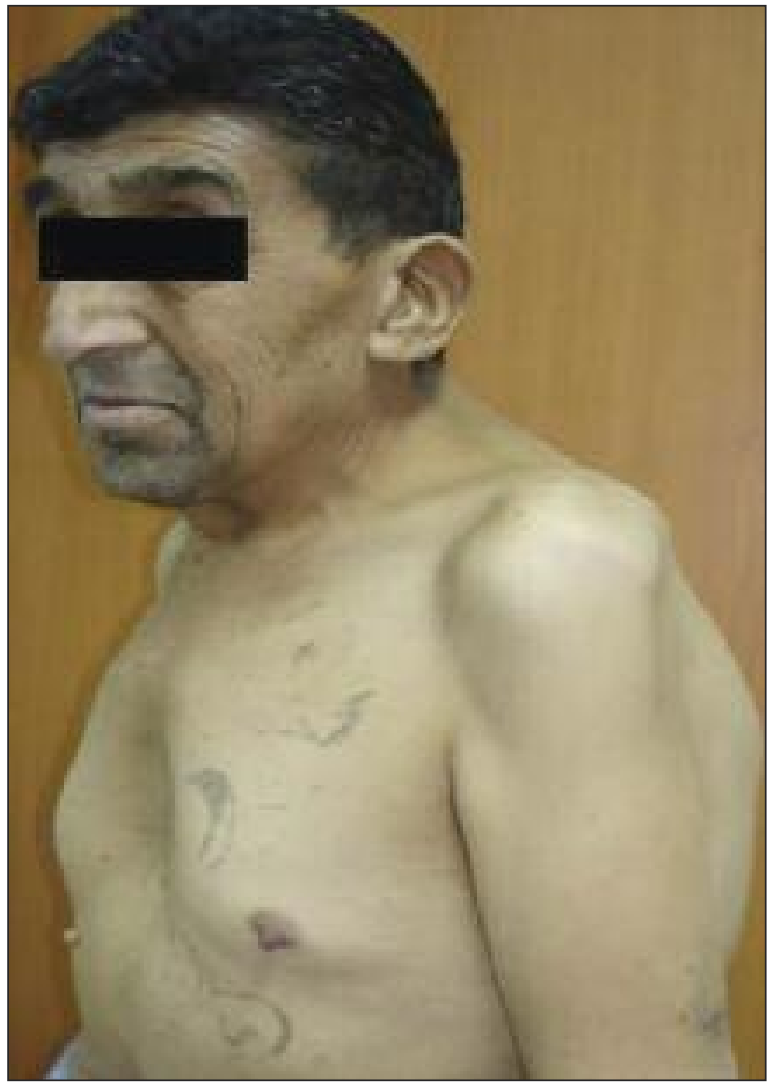

FIGURE 1: Typical appearance of face and thorax.

Chest X-ray (Figure 2a) revealed massive rightsided pleural effusion that proved to be chylothorax on biochemical analysis; total cholesterol level was $53 \mathrm{mg} / \mathrm{dL}$, triglyceride $514 \mathrm{mg} / \mathrm{dL}$, glucose 96 $\mathrm{mg} / \mathrm{dL}$, protein $4,1 \mathrm{mg} / \mathrm{dL}$, and lactate dehydroge-

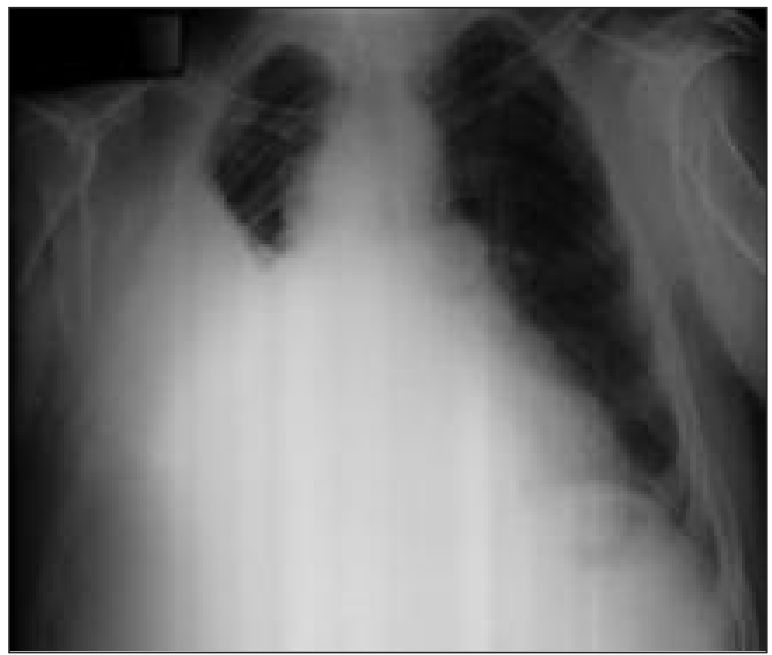

A

FIGURE 2: A. Chest X-ray before therapy showing massive chylothorax. B. Chest X-ray after therapy with significant resolution of pleural fluid nase $145 \mathrm{IU} / \mathrm{L}$ without any bacterial overgrowth. Chylous fluid $(1000 \mathrm{~mL})$ was drained by a pleural catheter daily for 21 days, until the treatment was started was. Other routine biochemical investigations, lymphoscintigraphy and positron emission tomography were unremarkable. Echocardiography revealed mitral valve prolapsus and minimal incompetence of mitral, aortic and tricuspid valves inconsistent with cardiac oscultation sounds; we could not hear the sounds of those abnormalities most probably due to thoracic deformity or large pleural collection. Pulmonary gradient was $30 \mathrm{mmHg}$ without any evidence of pericardial effusion. At the time of diagnosis computerized tomography of thorax and abdomen revealed that arcus aorta was right-sided in the upper mediastinum and the aorta was tortious in the abdomen. The left subclavian artery had a paraesophageal localization (Figure 3). The patient he was transported to surgical department for video assistant thoracoscopic surgery. Pulmonary embolism was diagnosed while the patient was being monitored preoperatively in thoracoscopic surgery department. The operation was postponed because of the pulmonary embolism and the patient was transferred back to our clinic for anticoagulant treatment. He was stable with this medication when we maintained an effective INR level without any change of cardiac sounds orchest $\mathrm{x}$-ray findings.

Diagnosis of Noonan Syndrome (NS) was estab-

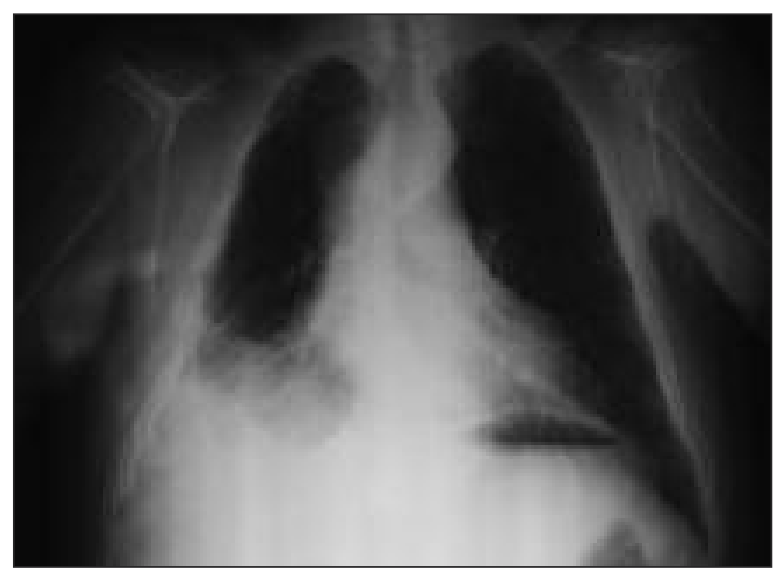

B 


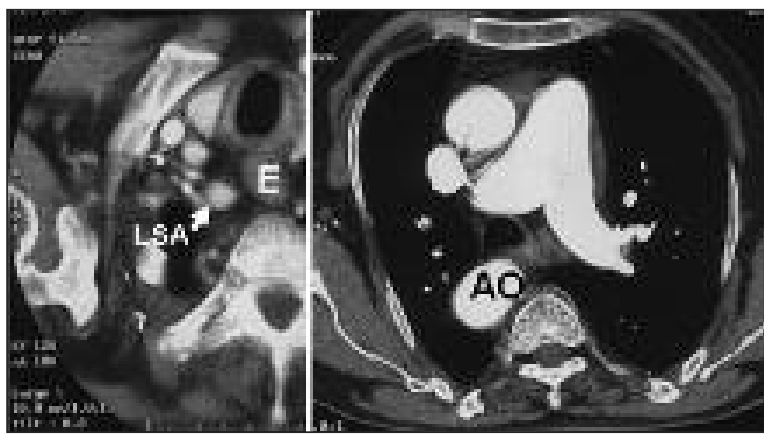

FIGURE 3: At the time of diagnosis, thorax CT showing paraesophageal location of left subclavian artery, right sided arcus aorta in upper mediastinum and tortuous abdominal aorta.

lished on the basis of chylothorax and specific morphological features. Octreotide was started on day 22 , initially with $3.5 \mu \mathrm{g} / \mathrm{kg}$ per hour and increased daily by $1 \mu \mathrm{g} / \mathrm{kg}$ per hour to $6.5 \mu \mathrm{g} / \mathrm{kg}$ per hour. Then it was switched to subcuteneous ocreotide (100 $\mu$ g every 8 hours) with an obvious clinical improvement. Additionally, an oral diet containing mediumchain triglycerides (MCT) was begun. The chylous fluid drainage was abruptly decreased to $100 \mathrm{~mL} /$ day on the first month after initiation of octreotide therapy and then chylothorax resolved immediately ( $\mathrm{Fi}^{-}$ gure $2 \mathrm{~b}$ ). He was discharged in a good condition on the $40^{\text {th }}$ day of admission. Six months later he was doing well without any complaints or effusion.

\section{DISCUSSION}

NS, is an autosomal dominant disorder commonly seen in childhood and is characterized by short stature, congenital heart defects and facial abnormalities (especially in adults) along with thoracic deformity. ${ }^{1}$ Facial features of NS include short and webbed neck, widely spaced nipples, mild mental retardation, bleeding diathesis and lymphatic dysplasia which more commonly is observed in neonates and infants as dorsal limb lymphedema. ${ }^{2}$ Missense mutations of PTPN11 gene on chromosome 12 are found in approximately $50 \%$ of the patients. ${ }^{3}$ The present patient was not tested for mutations in PTPN11 gene, but the clinical scoring system suggested by van der Burgt et al in 1994 supported the diagnosis (Table 1). ${ }^{4}$ His face was suggestive of the disease due to hypertelorism, down-slanting palpebral fissures, bilateral ptosis, strabismus and, low-set and posteriorly rotated ears. He had a short stature below 3rd centile, a characteristic chest deformity, lymphatic dysplasia and mild mental retardation. Additional features including short neck, widely spaced nipples and cardiovascular abnormality were supportive for the diagnosis. ${ }^{5,6}$

The mechanism causing chylothorax is lymphatic obstruction as a result of pulmonary lymphatic dysplasia, and it can account for development of fistulas between the thoracic duct and the pleural space. Malformation of thoracic lymphatic vessels causing chylothorax seems to be more frequent than anticipated. Lymphatic abnormalities occur in less than $20 \%$ of NS patients; ${ }^{7}$ however, how mutations of PTPN11 cause lymphatic dysplasia in these patients is yet unknown. ${ }^{2}$

To date there is no accepted treatment protocol for cylothorax. Conservative approach commencing low-fat/high-protein diet supplemented with MCT, and total parenteral nutrition are the

\begin{tabular}{|llll|}
\hline & \multicolumn{2}{c|}{ TABLE 1: Noonan Syndrome Clinical Scoring System* (van der Burgt et al., 1994) } \\
\hline Number & Features & Group A & Group B \\
\hline 1 & Facial & Typical face & Suggestive face \\
2 & Cardiac & Pulmonary valvular stenosis and/or typical ECG & Other defect \\
3 & Height & Below 3rd percentile & Below 10th percentile \\
4 & Chest wall & Pectus carinatum/excavatum & Broad thorax \\
5 & Family history & First degree relative with definite Noonan syndrome & First degree relative with suggestive Noonan syndrome \\
6 & Other & All three (for males): mental retardation, cryptorchidism, & One of mental retardation, cryptorchidism, \\
& & lymphatic dysplasia & lymphatic dysplasia \\
\hline
\end{tabular}

*: Definite diagnosis requires $1 \mathrm{~A}$, one of $2 \mathrm{~A}-6 \mathrm{~A}$ or two of $2 \mathrm{~B}-6 \mathrm{~B}$. It has also been mentioned that $1 \mathrm{~B}$ plus two of $2 \mathrm{~A}-6 \mathrm{~A}$ or three of $2 \mathrm{~B}-6 \mathrm{~B}$ can confirm the diagnosis. Our patient has the features of $3 \mathrm{~A}, 4 \mathrm{~A}, 1 \mathrm{~B}, 2 \mathrm{~B}$ and two of $6 \mathrm{~B}$ competible with the diagnosis (shown in bold). 
best choices along with pleural drainage. MCT are directly absorbed into the circulation allowing a reduction of lymphatic flow and healing of the damaged lymphatic vessels. Suggested medical therapy also includes a long-acting somatostatin analog, ocreotide. It acts directly on vascular somatostatin receptors and minimizes lymph fluid excretion by its vasoconstrictor effect. ${ }^{8}$ Moreover, by increasing splanchnic arteriolar resistance and decreasing gastrointestinal blood flow, octreotide indirectly reduces lymphatic flow. ${ }^{9}$ Side effects such as cutaneous flush, nausea, loose stools, transient hypothyroidism, elevated liver function tests, strangulation-ileus, transient abdominal distension, temporary hyperglycaemia and necrotising enterocolitis were reported. Potential adverse effects are fluid retention, hyponatremia, gastralgia, headache, nausea, vomiting, tympanites, and epistaxis. ${ }^{10}$ Surgical interventions, such as pleuroperitoneal shunting, pleurodesis, or direct ligation of the thoracic duct can be also be performed. ${ }^{8}$

We did not observe any therapy-related complications, The patient recovered quickly after the treatment beginned. Our findings suggest that, parenteral octreotide and oral MCT are effective, rather noninvasive, and safe agents. So they might be considered for treatment of chylothorax secondary to NS, and surgery might be reserved as a last option. It worths stressing that lymphatic dysplasia is among main clinical features of NS and this syndrome should be kept in mind in patients with suggestive features.

\section{REFERENCES}

1. Noonan JA. Hypertelorism with Turner phenotype. A new syndrome with associated congenital heart disease. Am J Dis Child 1968;116(4):373-80.

2. Ogata $T$, Sato $S$, Hasegawa $Y$, Kosaki K. Lymphstasis in a boy with Noonan syndrome: implication for the development of skeletal features. Endocr J 2003;50(3):319-24.

3. Tartaglia M, Mehler EL, Goldberg R, Zampino $\mathrm{G}$, Brunner HG, Kremer $\mathrm{H}$, et al. Mutations in PTPN11, encoding the protein tyrosine phosphatase SHP-2, cause Noonan syndrome. Nat Genet 2001;29(4):465-8.

4. van der Burgt I, Berends E, Lommen E, van Beersum S, Hamel B, Mariman E. Clinical and molecular studies in a large Dutch family with Noonan syndrome. Am J Med Genet 1994;53(2):187-91.

5. Onuk MD, Okçu N, Akarsu E, Çetinkaya R. [Noonan Syndrome: A case report]. Türkiye Klinikleri J Med Sci 1994;14(3):227-30.

6. Turan S. Bereket A. [Growth hormone treatment in childhood: to whom? when?] Türkiye Klinikleri J Pediatr Sci 2006;2(10):7-15.

7. Ho WL, Wang JK, Li YW. Radiological features of late-onset lymphoedema in Noonan's syndrome. Pediatr Radiol 2003;33(3):200-2.

8. Nakabayashi $H$, Sagara $H$, Usukura $N$, Yoshimitsu K, Imamura T, Seta T, et al. Ef- fect of somatostatin on the flow rate and triglyceride levels of thoracic duct lymph in normal and vagotomized dogs. Diabetes 1981;30(5):440-5.

9. Bac DJ, Van Hagen PM, Postema PT, ten Bokum AM, Zondervan PE, van Blankenstein M. Octreotide for protein-losing enteropathy with intestinal lymphangiectasia. Lancet 1995;345(8965):1639.

10. Roehr CC, Jung $A$, Proquitté $H$, Blankenstein $\mathrm{O}$, Hammer H, Lakhoo K, et al. Somatostatin or octreotide as treatment options for chylothorax in young children: a systematic review. Intensive Care Med 2006;32(5): 650-7. 